\title{
Procalcitonin measurements and non-invasive mechanical ventilation in acute exacerbation of COPD: an appropriate new tool?
}

Sir,

Hospitalization of acute exacerbations of chronic obstructive pulmonary disease (Ae-COPD) is a common health care problem. ${ }^{1}$ In last decades, non-invasive mechanical ventilation (NIV) is a key cornerstone therapeutic element that have shown influence positively short and long term outcomes in Ae-COPD. ${ }^{2,3}$ Recently, incorporation of new biomarkers as procalcitonin (PCT) to predict requirement of NIV in Ae-COPD is an attractive tool to guide a proper making decision regarding indication of NIV is scarce. ${ }^{4}$

Pazarli AC et al. analysed determinations of PCT levels among two selected COPD groups Ae-COPD (case group) compare to stable COPD as control group. ${ }^{5}$ In this original study, aims were analyse if PCT level was predictive of Ae-COPD assessment of severity and its potential value to planning NIV requirements. This study present a novel utility of applications of biomarkers and major findings discover were that mean levels of PCT in Ae-COPD was significantly higher than COPD in stable conditions and that PCT cut-off value for NIV indication was $0.10 \mathrm{ng} / \mathrm{ml}$. These results are original and add a great practice valour for NIV organization. However, there are some points of interest to take into account that could influence role of PCT level and use of NIV.

First at all, regarding decisions for indication of the NIV in Ae-COPD, it is well known for clinical and epidemiological studies that "real world" the final NIV indications and decisions by physicians are subject to others local or structural factors that were not reported by Pazarli AC et al. and could need some clarifications especially for a proper clinical practice extrapolation of PCT utility. Briefly, in this study use of NIV in AeCOPD could be influence by a) rate of volume-cases of Ae-COPD patients hospitalized admitted $\left.{ }^{6} ; b\right)$ level of skill and team experience, c) intrinsic-factor patient depended as level of consciousness. ${ }^{7,8}$

Secondly, regarding level of applicability of PCT rate of sensibility and specific COPD populations Ae-COPD versus COPD stable need some clarifications that could are acting in NIV response and in short hospital outcome did not report such as: a) number of previous CODP readmissions rates and frequency, b) comorbid conditions c) severity and aetiology of Ae-COPD ${ }^{9}$ and e) correlation between levels of COPD-Gold Stage and levels of PCT. In this last point, Falsey AR et al shown in a very exhaustive study that it is necessary to differentiate in Ae-COPD and use of PCT differentiate bacterial or viral as key factor.

Finally, regarding correlations of PCT levels an arterial blood gases (ABG) in Ae-COPD that potential need NIV, we know that $\mathrm{ABG}$ basal levels and trends of $\mathrm{pH} / \mathrm{pCO} 2$ measurements at admissions are influenced by a complex interactions as Ae-COPD severity, underling pulmonary functions derangements and NIV setting and hospital protocols. ${ }^{10}$ These factors could be necessary to comment by Pazarli AC et al. Further, large prospective clinical trials need clarification regarding how incorporate PCT levels and trends measurements and NIV applications in hospital protocol for Ae-COPD. ${ }^{5}$

Antonio M. Esquinas

Intensive Care Unit and Non Invasive Ventilation Unit, Hospital Morales Meseguer, Murcia, Spain

*Correspondence to: Dr. Antonio M. Esquinas, Email: antmesquinas@gmail.com

\section{REFERENCES}

1. Toy EL, Gallagher KF, Stanley EL, Swensen AR, Duh MS. The economic impact of exacerbations of chronic obstructive pulmonary disease and exacerbation definition: a review. COPD 2010; 7(3):214-28.

2. Keenan PS, Sinuff T, Cook DJ, Hill NS. Which patients with acute exacerbation of chronic obstructive pulmonary disease benefit from noninvasive positive-pressure ventilation? A systematic review of the literature. Ann Intern Med 2003, 138(11):861-70.

3. Ram FS, Lightowler JV, Wedzicha JA. Noninvasive positive pressure ventilation for treatment of respiratory failure due to exacerbations of chronic obstructive pulmonary disease. Cochrane Database Syst Rev 2003; (1):CD004104.

4. Falsey AR, Becker KL, Swinburne AJ, Nylen ES, Snider RH, Formica MA, Hennessey PA, Criddle MM, Peterson DR, Walsh EE. Utility of serum 
procalcitonin values in patients with acute exacerbations of chronic obstructive pulmonary disease: a cautionary note. Int $\mathbf{J}$ Chron Obstruct Pulmon Dis 2012; 7:127-35.

5. Pazarli AC, Koseoglu HI, Doruk S, Sahin S, Etikan I, Celikel S, Berktas B. Procalcitonin: Is it a predictor of noninvasive positive pressure ventilation necessity in acute chronic obstructive pulmonary disease exacerbation? J Res Med Sci 2012;17(11):1047-51.

6. Dres M, Tran TC, Aegerter P, Rabbat A, Guidet B, Huchon G, Roche N; CUB-REA Group. Influence of ICU case-volume on the management and hospital outcomes of acute exacerbations of chronic obstructive pulmonary disease. Crit Care Med 2013;41(8):1884-92.

7. Berkius J, Sundh J, Nilholm L, Fredrikson M, Walther SM. What determines immediate use of invasive ventilation in patients with COPD? Acta Anaesthesiol Scand 2013;57(3):312-9.

8. Tøttenborg SS, Johnsen SP, Thomsen RW, Nielsen $H$, Hansen EF, Lange P. Use of non-invasive ventilation is increasing in patients admitted with a chronic obstructive pulmonary disease exacerbation. Dan Med J 2013;60(8):A4686.

9. Agarwal R, Gupta R, Aggarwal AN, Gupta D. Noninvasive positive pressure ventilation in acute respiratory failure due to COPD vs other causes: effectiveness and predictors of failure in a respiratory ICU in North India. Int J Chron Obstruct Pulmon Dis 2008;3(4):737-43.

10. Khilnani GC, Saikia N, Banga A, Sharma SK. Noninvasive ventilation for acute exacerbation of COPD with very high $\mathrm{PaCO}(2)$ : A randomized controlled trial. Lung India 2010;27(3):125-30.

DOI: 10.5455/2320-6012.ijrms20140278

Cite this article as: Esquinas AM. Procalcitonin measurements and non-invasive mechanical ventilation in acute exacerbation of COPD: an appropriate new tool? Int J Res Med Sci 2014;2:3734. 